\title{
Topical Medicine Potency of Musa paradisiaca var. sapientum (L.) kuntze as Oral Gel for Wound Healing: An In Vitro, In Vivo Study
}

\author{
Hendrik Setia Budi ${ }^{1}$ (1) \\ Mohammed Aljunaid ${ }^{5}$ (i) \\ Silvia Anitasari 2,3 \\ Doaa Elsayed Ramadan 6 \\ ${ }^{1}$ Department of Oral Biology, Faculty of Dental Medicine, Universitas \\ Airlangga, Surabaya, Indonesia \\ 2 Department of Dental Material and Devices, Faculty of Medicine, \\ Universitas Mulawarman, Samarinda, Indonesia \\ ${ }^{3}$ Department of Medical Microbiology, Faculty of Medicine, \\ Universitas Mulawarman, Samarinda, Indonesia \\ ${ }^{4}$ Surabaya Pharmacy Academy, Surabaya, Indonesia \\ ${ }^{5}$ Faculty of Dental Medicine, Alsaeed University, Taiz, Yemen \\ ${ }^{6}$ Ministry of Health and Population, Cairo, Egypt
}

Ninik Mas Ulfa 4

\author{
Address for correspondence Hendrik Setia Budi, DDS, MS, PhD, \\ Department of Oral Biology, Faculty of Dental Medicine, Universitas \\ Airlangga, Jl. Mayjend. Prof. Dr. Moestopo No. 47 Surabaya 60132, \\ Indonesia (e-mail: hendrik-s-b@fkg.unair.ac.id). \\ ${ }^{7}$ Faculty of Dental Medicine, Universitas Airlangga, Surabaya, \\ Indonesia \\ ${ }^{8}$ School of Dental Technology, College of Oral Medicine, Taipei \\ Medical University, Taipei, Taiwan
}

Eur J Dent 2022;16:848-855.

\section{Abstract \\ Keywords \\ - drug compounding \\ - drug stability \\ - health risk \\ - oral gel \\ - wound healing}

Objective Topical application of ambonese banana (Musa paradisiaca var. sapientum (L.) kuntze) stem sap gel (GEGPA) on the socket wound area showed an increase in the expression of platelet-derived growth factor-BB, while decrease in the expression of matrix metalloproteinase-2 and 9. The aim of this study is to achieve standard formulation of GEGPA through stability, viscosity, distribution area, and drugs release for oral gel wound healing. Materials and Methods This is an in vitro and in vivo study with the randomized posttest only control group design. The gel was formulated according to the composition of each group by adding hydroxypropyl methylcellulose (HPMC), Lexgard, propylene glycol, and cold water to obtain $100 \mathrm{~g}$ of gel. Observations were made through the following tests: stability, viscosity, distribution area, drug release, and histopathological analysis of tooth extraction wound healing.

Statistical analysis Data were analyzed using a one-way analysis of variance ( $\alpha=$ 0.05) with GraphPad Prism-8 statistical software.

Results The study showed that the GEGPA formulation was stable against changes in consistency, color, smell, homogeneity, and $\mathrm{pH}$ value. There is a significant difference between groups with respect to viscosity $(p=0.0001)$, adhesion $(p=0.004)$, dispersion $(p=0.000)$, and fibroblast cell numbers on days 3 and $5(p=0.007$ and $p=0.001)$. There is no interaction between the active ingredients and the gel base of all formulations. Formulation 3 had better properties in terms of viscosity, broad distribution, and drug release compared with other groups. Application of GEGPA to tooth extraction wounds showed a significant proliferation of fibroblast cells on days 3 and 5.

Conclusions The formulation of $M$. paradisiaca var. sapientum (L.) kuntze extract with HPMC and propylene glycol obtained a gel preparation, GEGPA, that was organoleptically stable and met the topical gel standard for wounds in the oral cavity. published online

February 18, 2022
DOI https://doi.org/

10.1055/s-0041-1740226. ISSN 1305-7456.

\section{(C) 2022. The Author(s).}

This is an open access article published by Thieme under the terms of the Creative Commons Attribution License, permitting unrestricted use, distribution, and reproduction so long as the original work is properly cited. (https://creativecommons.org/licenses/by/4.0/)

Thieme Medical and Scientific Publishers Pvt. Ltd., A-12, 2nd Floor, Sector 2, Noida-201301 UP, India 


\section{Introduction}

Wound healing is a defense mechanism that works by repairing damaged cells or tissues. ${ }^{1,2}$ The healing consists of a complex series of biological processes that involve cells and surrounding tissues supported by inflammatory and anti-inflammatory cytokines. The oral cavity is a remarkable environment in which wound healing process occurs in the presence of millions of microorganisms in warm oral fluids. ${ }^{3}$ Topical or oral medications are used to localize wounds, relieve pain, prevent contamination, and promote healing. ${ }^{4,5}$

The drug can be administered topically by applying it on the skin or mucosal surface. ${ }^{6}$ Drugs that are commonly used for topical administration to the skin are usually in the form of creams, lotions, or ointments, ${ }^{7}$ while drugs that are usually used for treating oral mucosa wounds are generally in the form of gels. ${ }^{8,9}$ The success of topical treatment depends on patient age, selection of appropriate topical agents, location and area of the affected or diseased body, stage of disease, the concentration of active ingredients in the vehicle, methods of application, determination of druguse duration, and penetration of the topical drug into the skin/mucosa. ${ }^{10-12}$ Topical drug administration may be considered in patients with gastrointestinal disturbances, contraindications, or difficulty of swallowing. ${ }^{13}$

Ambonese banana (Musa paradisiaca var. sapientum (L.) kuntze) is one of the tropical plants that are often used as herbal medicines. The banana tree can be used as an alternative in the treatment of wounds, fevers, insect bites, digestive disorders, and epilepsy. ${ }^{14}$ The stem sap extract of ambonese banana contains lectins, palmitic acid, leucocyanidin, quercetin, 3-O-galactoside, 3-O-glucoside, and 3-O-rhamnosyl glucoside, ${ }^{15}$ and has analgesic, anti-inflammatory, antibacterial, ${ }^{16}$ and antioxidant properties. ${ }^{17}$ These also increase fibroblasts proliferation through the induction of growth factors such as platelet-derived growth factor-BB (PDGF-BB) and transforming growth factor- $\beta 1$ (TGF- $\beta 1$ ). ${ }^{18}$ The use of ambonese banana stem sap extract gel (GEGPA) in fibroblast cell culture shows that it is relatively nontoxic up to a concentration of $100 \%{ }^{19}$ The increase in collagen in the wound area that was given the GEGPA can be caused by decrease in matrix metalloproteinase- 2 and 9 expressions, as well as the antioxidant activity of active compounds in it. ${ }^{20}$ The gel consistency greatly affects the ease of its application on the oral wound area. The use of gel-forming materials such as hydroxypropyl methylcellulose (HPMC) in the preparation of ambonese banana stem sap extract has not been proven to interfere the wound healing process after extractions.

The gel is a semi-solid form that is clear, translucent, and contains active substances. It is also a colloidal dispersion that has force caused by tissues that are bonded to each other in the dispersed phase. ${ }^{21}$ This gel form has several advantages such as its nonstickiness, the little concentration of gelling agents that is required to form good gel mass, and the gel viscosity that will not change significantly at storage temperature. ${ }^{22}$ Every drug should have a good stability; therefore, the pharmaceutical form must be considered carefully. This is very important considering the drug forms that are generally made in large quantities and require long- term storage. If a drug is stored for a long period of time, it can decompose and result in the reduced effects received by the patient. ${ }^{23} \mathrm{~A}$ good formulation is needed for optimum drug stability and the factors that influence the stability of a new drug. This study aims to obtain a suitable gel formulation, so that the stability, viscosity, distribution, and release of active compounds in ambonese banana stem sap extract are maintained as a potential drug.

\section{Materials and Methods}

\section{Ambonese Banana Stem Sap Preparation}

The plant was determinated in the Lembaga Ilmu Pengetahuan Indonesia, Purwodadi, East Java. Ambonese banana stems were cleaned of dirt with running water. The sap from the ambonese banana stem was taken by extracting it. The stems were cut into thin strips with a thickness of 0.5 to $1 \mathrm{~cm}$ and dried using an oven (MMM, GmbH) at $40^{\circ} \mathrm{C}$ for 3 hours. The dried stems were made into powder and then weighed as much as $1 \mathrm{~kg}$. The maceration process was performed with 2 liters of $96 \%$ ethanol. The maceration process with ethanol solvent was performed twice, up to 7 days. The results of the maceration were filtered using filter paper (Whatman number 41), and then separated between the extract and solvent using an evaporator (Heidolph-VAP, Germany) at $40^{\circ} \mathrm{C}$ with $200 \mathrm{rpm}$ speed for 2 hours, to obtain a thick extract. The extract was stored in a closed, dark container and protected from light.

\section{Ambonese Banana Stem Sap Gel (GEGPA) Formulation} The gel was formulated according to the composition in - Table 1, and the required ingredients were weighed. HPMC was dispersed into $30 \mathrm{~mL}$ of water at 80 to $90^{\circ} \mathrm{C}$ until it expanded. It was then stirred until a clay (gel) was formed. The stirring process must be in a cold state such as a basin that had been given ice cubes. Lexgard was mixed in propylene glycol according to the groups (F1, F2, F3); then the extract was added until it was properly mixed. The mixture was added to the HPMC mixture and stirred until it was homogeneous. Cold water was added to get $100 \mathrm{~g}$ of gel; then it was packed in a tightly sealed tube. In the control group (K), no extract was added.

Table 1 The formulation of the ambonese banana hump extract gel (GEGPA)

\begin{tabular}{|l|l|l|l|}
\hline \multirow{2}{*}{ Material } & \multicolumn{3}{|l|}{$\begin{array}{l}\text { Material concentration } \\
\text { (\% b/b) }\end{array}$} \\
\cline { 2 - 4 } & F1 & F2 & F3 \\
\hline Active material & 1 & 1 & 1 \\
\hline HPMC & 4 & 4 & 4 \\
\hline Propylene glycol & 10 & 15 & 20 \\
\hline Lexgard & 0.01 & 0.01 & 0.01 \\
\hline Aqua ad & 100 & 100 & 100 \\
\hline
\end{tabular}

Abbreviations: F1, formulation 1; F2, formulation 2; F3, formulation 3; HPMC, hydroxypropyl methylcellulose. 


\section{Gel Stability Test}

The stability of GEGPA was tested at room temperature by observing (organoleptic) the color, smell, homogeneity, $\mathrm{pH}$, and viscosity. ${ }^{24}$ Samples were stored at $4^{\circ} \mathrm{C}$ for 24 hours. After that, the samples were taken out and placed at $40^{\circ} \mathrm{C}$ for 24 hours. This treatment is counted as one cycle. The experiment was repeated for six cycles while taking the physical conditions into account during the experiment by comparing the previous forms.

\section{Gel pH Test}

$\mathrm{pH}$ testing on GEGPA was done by inserting the $\mathrm{pH}$ meter electrode (Mettler Toledo S220, Merck) into the gel. ${ }^{24}$ The gel's pH value will be displayed on the $\mathrm{pH}$ meter's screen. The recording of the $\mathrm{pH}$ value is awaited until the number on the screen does not change (stable). A suitable gel preparation has a $\mathrm{pH}$ value that is near to the oral $\mathrm{pH}$, which is between 6.2 and 7.6.

\section{Gel Viscosity Test}

The viscosity test is used to determine the viscosity of the gel preparation by using a viscometer (Haake 6R viscometer, Thermo Scientific, Germany). ${ }^{24}$ The gel preparation sample was put into a glass beaker and placed under a spindle hanger. The spindle is installed on the spindle hanger; then it was lowered to the limit immersed in the extract gel preparation. Next, the rotor was turned on while pressing the button. The spindle was allowed to rotate and the red needle was observed on the scale; then the number indicated by the needle was read.

\section{Gel Homogeneity Test}

The homogeneity test was performed by weighing $0.1 \mathrm{~g}$ of each sample. Furthermore, the sample is smeared on an object glass, and the homogeneity of the preparation and the presence of air bubbles were observed under a microscope at a $100 \times$ magnification. ${ }^{24}$

\section{Gel Adhesion Test}

The adhesion test was performed by means of $0.25 \mathrm{~g}$ of sample placed on top of two predetermined glass objects, then pressed with a load of $1 \mathrm{~kg}$ for 5 minutes. The glass object was put on the test equipment and then a load of $80 \mathrm{~g}$ was added. The time it takes for the glass object to come off is the stickiness ability of the gel that is going to be recorded and tabulated. ${ }^{25}$

\section{Gel Dispersion Test}

The dispersion test was performed by weighing the gel preparation as much as $0.5 \mathrm{~g}$; after that the gel was placed right under a round glass underneath, accompanied by a diameter scale. Next, it was covered with another glass that had been weighed and then allowed to sit for 1 minute. The scatter diameter of each gel was then measured. After 1 minute, a $50 \mathrm{~g}$ load was added and allowed to sit for 1 minute. Next, the diameter of the spread was remeasured. This was repeated every 1 minute with the addition of a $50 \mathrm{~g}$ load until a sufficient diameter was obtained to observe the effect of the load on the diameter of the spread of the gel preparation. $^{25}$

\section{Power of Diffusion and Permeation Tests}

The gel diffusion test was performed with a Millipore synthetic membrane, which was placed between two halves of the diffusion cell. Then, the receptor was filled with phosphate buffer of $6.8 \mathrm{pH}$ and $5 \%$ ethanol to $130 \mathrm{~mL}$ at $37^{\circ} \mathrm{C}$. One gram of gel was applied to the membrane. The absorption was measured every 30 minutes to 8 hours at a $274 \mathrm{~nm}$ wavelength with an ultraviolet-visible spectrophotometer (Shimadzu 1800). ${ }^{25}$

\section{Histopathology of Fibroblast Cells on Tooth Socket Wound Healing}

This research has passed the health ethics test with number: 586/HRECC.FODM/IX/2020. The experimental animals were 24 male rats, Wistar type, 2 to 3 months old, and divided into 4 groups. Rats were anesthetized according to their body weight $(30 \mathrm{mg} / \mathrm{kg}$ thionembutal). After the rats were anesthetized, the wound was made by extracting the mandibular left incisor. ${ }^{26}$ In the control group (K), the socket was only given the drug carrier gel. The treatment group was given GEGPA with different formulations, namely F1, F2, and F3. The gel was injected into the dental socket of Wistar rats using modified needle (as much as 1 to $2 \mathrm{~mL}$ of tuberculin syringe). After tooth extraction, the wound was closed by suturing using 5-0 Vicryl (Ethicon, Johnson \& Johnson do Brasil, São Jose dos Campos, SP, Brazil). Decapitation was performed on days 3 and 5; then the tissue was washed to remove the residual blood with $0.9 \%$ sodium chloride physiological solution and fixed using $10 \%$ neutral buffer formalin. The mandible bone was decalcified using $10 \%$ ethylenediaminetetraacetic acid (Sigma) and then paraffin blocks were made. The preparations were made with a $4 \mu$ thickness for histological examination of fibroblast cells in the apical one-third of the extraction socket. The preparations were observed using a light microscope (Nikon H600L) with $400 \times$ magnification in five fields of view, equipped with a calibrated micrometer. The preparations were processed using the Nikon Image System software and a 300 megapixels DS Fi2 digital camera.

\section{Statistical Analysis}

Data were tabulated and analyzed using a one-way analysis of variance (ANOVA) test with GraphPad Prism-8 statistical software at $95 \%$ significance. Differences in the mean value of viscosity, adhesion, dispersion, and the number of fibroblasts were analyzed statistically by one-way ANOVA. The gel diffusion and permeation data were analyzed by regression.

\section{Results}

\section{Organoleptic Observations of GEGPA}

The four formulations showed that in the control group a clear, homogeneous gel was formed, with a typical smell of 
Table 2 Organoleptic observations of gel formulations

\begin{tabular}{|l|l|l|l|l|}
\hline \multirow{2}{*}{ Physical properties test } & \multicolumn{4}{|l|}{ Formula } \\
\cline { 2 - 5 } & Control (Base) & F1 & F2 & F3 \\
\hline Color & Clear & Clear brown & Clear brown & Clear brown \\
\hline smell & Typical base & Specialty banana & Specialty banana & Specialty banana \\
\hline pH & 6.8 & 6.7 & 6.7 & 6.8 \\
\hline Viscosity & Thick & Thick & Thick & Thick \\
\hline Homogeneity & Homogeneous & Homogeneous & Homogeneous & Homogeneous \\
\hline
\end{tabular}

Abbreviations: F1, formulation 1; F2, formulation 2; F3, formulation 3; HPMC, hydroxypropyl methylcellulose.

Note: Description: Control, base (HPMC 4\%), F1, Eq. 1, F2; Eq. 2; F3, Eq. 3.

gel base, $6.8 \mathrm{pH}$, and thick viscosity. In the three groups of GEGPA formulations, there are no organoleptic differences between the gel samples. The gel is clear brown, homogeneous, has a typical banana smell, and thick viscosity. The experiment was repeated for six cycles and compared with the previous forms. Physically, no significant change is found between groups with respect to color, smell, homogeneity, $\mathrm{pH}$, and viscosity, but there is a decrease in the $\mathrm{pH}$ of 0.1 in the F1 and F2 groups. The formulation of F3 is more stable compared with the treatment groups ( - Table 2 ).

\section{The Difference in Gel Viscosity of GEGPA}

Viscosity testing aims to determine the value of the viscosity of a substance. The higher viscosity of the gel will make the gel thicker resulting in more difficult drug to spread. There is a decrease in the viscosity of each formulation with increase in the volume of propylene glycol that had been used. Sequentially, the highest viscosity values are: the control group2009; 003E;2009;F12009;003E;2009;F22009;003E;2009;F3, with a value of 3,592; 3,187; 2,438; and 2,035 cps 0028; - Fig. 10029;. There is a significant difference in the viscosity values of each group 0028;p2009;003D;2009;0.00010029.

\section{Gel Adhesion Ability of GEGPA}

The gel adhesion test is intended to determine the ability of the gel to adhere to the oral mucosa. The gel adhesion test was evaluated by observing the length of time the glass objects remained attached. There is a significant decrease in the length of attachment time in each group $(p=0.004)$. Obviously, the GEGPA formulation can affect the time length of adhesion (-Fig. 2).

\section{Gel Dispersion of GECPA}

Gel examination is intended to determine the ability of the gel to spread in the oral mucosa. The GEGPA distribution in the F3 group was wider than in the other groups ( - Fig. 3 ). Sequentially, the widest dispersion ability is: F3 $>$ F2 $>$ F1 $>$ control, with a value of $21.76,17.91,14.05$, and $12.37 \mathrm{~mm}^{2}$ (-Fig. 4). There is a significant difference in dispersion ability between groups $(p=0.000)$.

\section{Diffusion and Penetration of GEGPA across Membranes}

As per the results ( $\mathbf{- F i g . 5}$ ), the spectrophotometer data for the maximum absorbance of the gel are at $274 \mathrm{~nm}$ wavelength in a 6.8 phosphate buffer solution. Referring to Lambert Beer's law of the standard solution with a concentration of 10 to $180 \mu \mathrm{g}$, it is found that the linearity $\left(r^{2}\right)$ is 0.999 , and regression value $(Y)$ is $0.0171 \mathrm{X}+0.003$. From this graph, the results indicate that there is no interaction between the active ingredients and the gel base of all formulations (F1, F2, and F3).

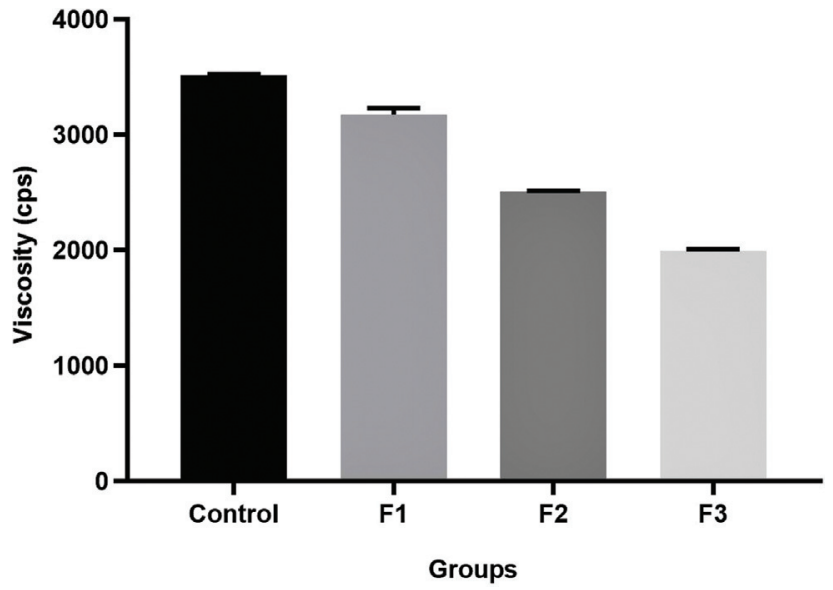

Fig. 1 Viscosity of ambonese banana stem sap extract gel. F1, formulation 1; F2, formulation 2; F3, formulation 3 .

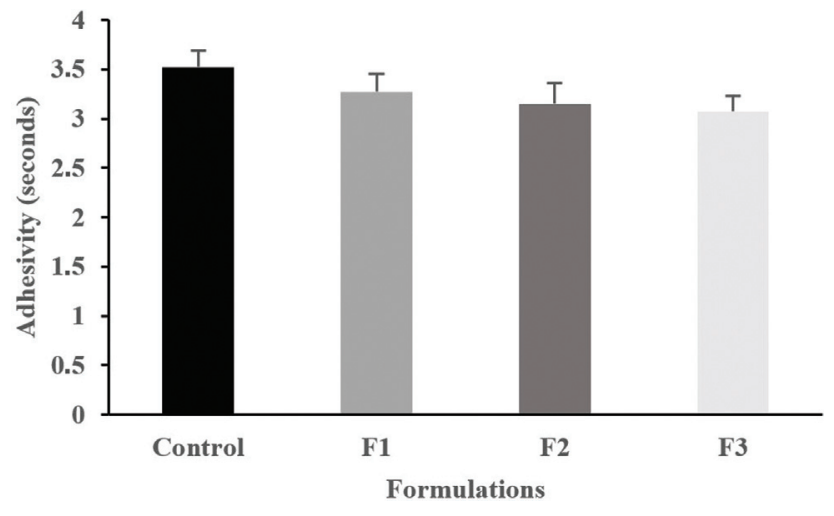

Fig. 2 Average gel adhesion strength. F1, formulation 1; F2, formulation 2; F3, formulation 3. 


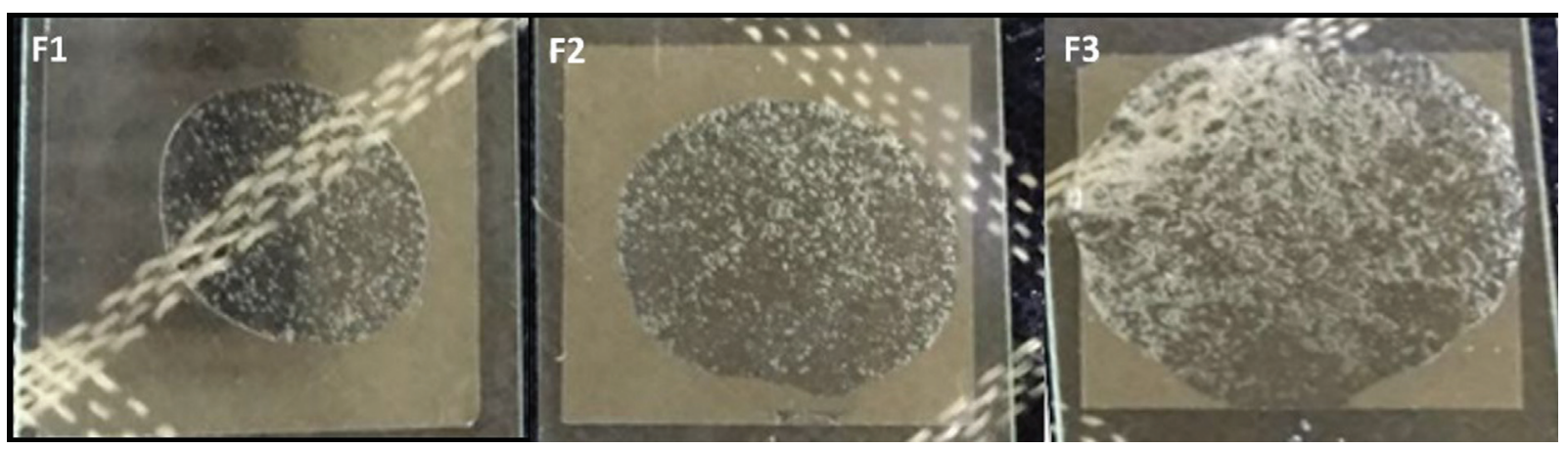

Fig. 3 Differences in the spread of gel in ambonese banana stem sap gel groups. F1, formulation 1; F2, formulation 2; F3, formulation 3.

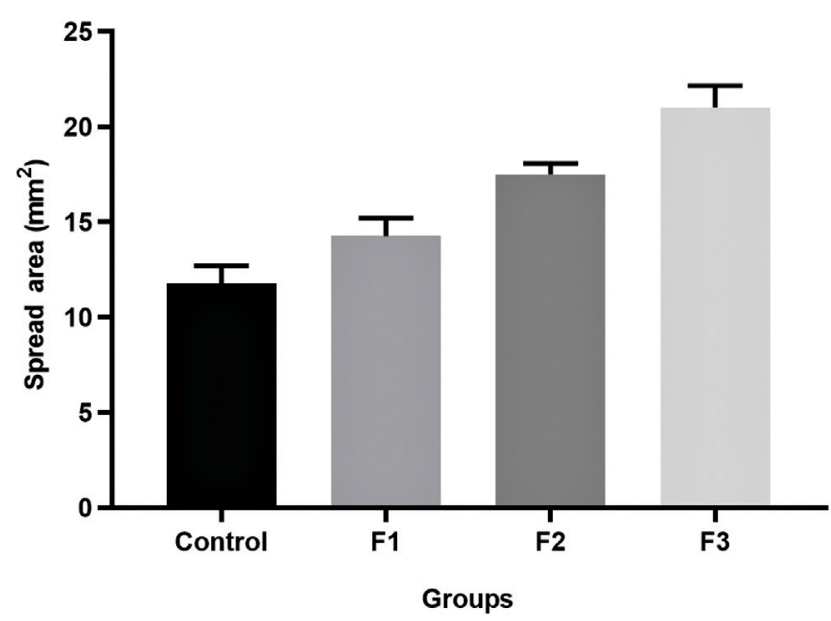

Fig. 4 Differences in dispersion between groups of gels. F1, formulation 1; F2, formulation 2; F3, formulation 3.

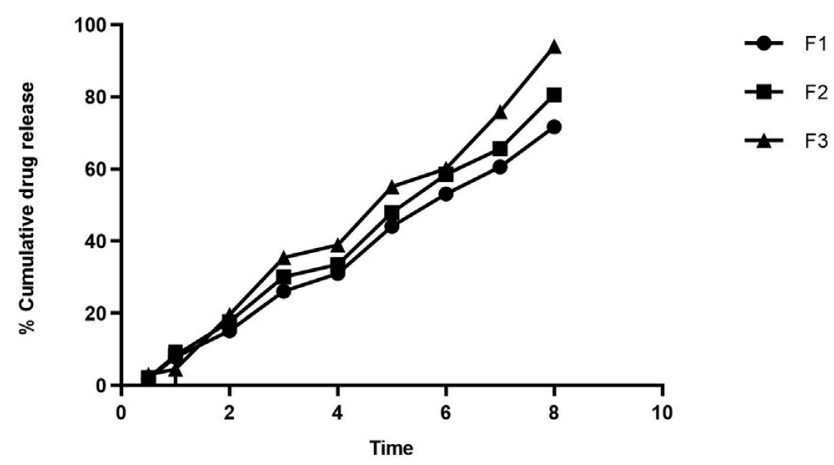

Fig. 5 Diffusion and permeation power of ambonese banana stem sap gel. F1, formulation $1 ; F 2$, formulation 2 ; F3, formulation 3 .

\section{Fibroblast Proliferation in the Healing Process of Tooth Sockets}

There is a significant increase in the number of fibroblast cells in the tooth socket on healing days 3 and 5 in the groups that were given GEGPA, which are F1, F2, and F3, compared with the control group ( $p=0.007$ and $p=0.001$; - Table 3 ). The apical one-third of the socket in groups F1, F2, and F3 appears to be filled with fibroblast cells more rapidly (-Fig. 6). There is no significant difference in the number of fibroblasts in the F1, F2, and F3 groups on days 3 and 5 $(p=0.207$ and $p=0.112)$. The number of fibroblast cells in
Table 3 The average number of fibroblast cell proliferation on days 3 and 5

\begin{tabular}{|c|c|c|c|c|}
\hline \multirow[t]{2}{*}{ Groups } & \multicolumn{4}{|c|}{ Count of fibroblast cells $(\overline{\mathrm{x}} \pm \mathrm{SD})$} \\
\hline & Day 3 & $p$-Value & Day 5 & $p$-Value \\
\hline Control & $8.3 \pm 0.52$ & \multirow[t]{4}{*}{$0.007^{\mathrm{a}}$} & $12.1 \pm 0.86$ & \multirow[t]{4}{*}{$0.001^{\mathrm{a}}$} \\
\hline F1 & $16.7 \pm 0.75$ & & $22.3 \pm 1.13$ & \\
\hline F2 & $18.1 \pm 0.66$ & & $24.3 \pm 1.02$ & \\
\hline F3 & $8.3 \pm 0.52$ & & $25.7 \pm 1.15$ & \\
\hline
\end{tabular}

Abbreviations: SD, standard deviation; $\bar{x}$, mean.

${ }^{a} p$-Value, significance level 0.05 .

the control group appears to be lesser than the group given GEGPA.

\section{Discussion}

A lot of research has been done to get a material that can accelerate the wound healing process in the oral cavity, as well as reduce postoperative complications. In controlling complex microorganisms in the oral cavity, topical wound protection agents are surely needed, besides oral drugs to reduce pain, inflammation, and infection. Oral drug use will give absorption, metabolism, distribution, and excretion (ADME) effect, as well as first-pass metabolism. ${ }^{27,28}$ Disruption of ADME results in reduced drug availability in the systemic circulation, and low-found drug concentrations in tissue. ${ }^{29}$ Recent researches in dentistry are mainly focused on the development of local agent's use or drugs that are applied directly to the wound area. It is hoped that the local/topical administration will be more effective because it can be absorbed directly and interact with surrounding cells and tissues. Oral gel formulations may reduce side-effects in patients with gastrointestinal disorders if taken orally, or in patients with medical conditions such as dysphagia. ${ }^{30}$ In addition, there are many oral gel products that are available commercially, most of which are quick-release formulations that release the active ingredient by diffusion. ${ }^{31}$

In this study, HPMC was used for making the GEGPA preparations, which act as a gelling agent. HPMC will form a colloidal system when dissolved in water. Lipophilic colloids are generally organic molecules that can be dissolved with molecules from the dispersing phase. ${ }^{22}$ HPMC is nontoxic and has good water binding ability. ${ }^{32}$ The use of $4 \%$ HPMC in GEGPA preparations produces the appropriate 


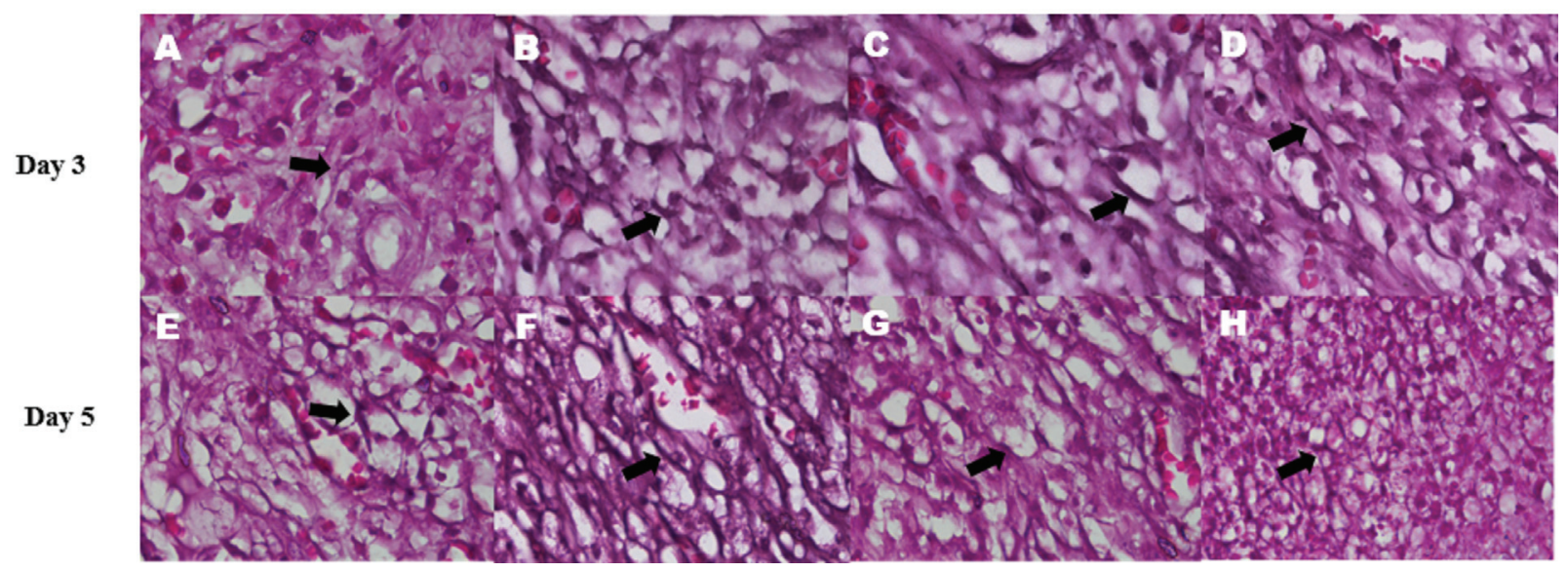

Fig. 6 The difference in the number of fibroblast cells (arrows) between groups with hematoxylin-eosin staining. Fibroblast cells proliferation on day 3: Control (A), formulation F1 (B), formulation F2 (C), and formulation F3 (D). Fibroblast cells proliferation on day 5: Control (E), formulation F1 (F), formulation F2 (G), and formulation F3 (H). 400x magnification, Nikon H600L microscope, DS Fi2 camera 300 megapixels.

viscosity and can hold blood out of wounds as found in the result of the extraction of rat teeth. ${ }^{18,20} \mathrm{~A}$ topical preparation's solubility can be increased by adding a cosolvent or a solubility-enhancing compound. One of the cosolvents that is often used in gel preparations is propylene glycol with a concentration of 5 to $80 \%{ }^{33}$

A formulation of propylene glycol cosolvent with a concentration of 10 to $20 \%$ was used for oral gel preparations. The use of propylene glycol can also increase drug penetration. ${ }^{34}$ Propylene glycol is used because it has hydrophilic and hydrophobic groups, so it can dissolve hydrophobic compounds. ${ }^{35}$ In addition, propylene glycol is a cosolvent with low toxicity. ${ }^{36}$ GEGPA formulations that consist of ambonese banana stem extracts, HPMC, and propylene glycol, produced a brownish clear gel with thick viscosity and a typical banana scent. The GEGPA formulation has a slightly decreased $\mathrm{pH}$, namely by 0.1 , compared with the $\mathrm{pH}$ of the control group, which is 6.8. The pH value of GEGPA still meets the requirements for a normal oral $\mathrm{pH}$ environment, which is between 6.7 and 7.3, and saliva with a pH between 6.2 and 6.7. ${ }^{37}$ The use of $20 \%$ propylene glycol can balance the $\mathrm{pH}$ of GEGPA, so that it becomes the same as the $\mathrm{pH}$ of the control group. It is possible because in GEGPA preparations, the compound in ambonese banana stem sap can lower the $\mathrm{pH}$ of propylene from 9.0-10.5 to 6.7-6.8.

The viscosity of the GEGPA formulation is also less compared with the control group. A good gel has a viscosity between 2,000 and 4,000 cps. ${ }^{38,39}$ The GEGPA formulation has a viscosity between 2,035 and 3,187 cps, so the results of this study indicate that the GEGPA formulation meets the requirements of a fairly good oral gel. Due to the encouragement of blood flow that comes out of the wound, the appropriate gel viscosity can inhibit gel detachment from the mucosa.

The thicker the gel or the higher the viscosity of the gel, the more difficult it is for the active ingredient to be separated from the carrier material and the longer is the penetration time into the tissue, so the absorption of the active ingredient can decrease. The increase in viscosity can also affect the adhesion of the gel to the mucosa. The gel is considered appropriate when the drug can diffuse quickly into the wound.

The dispersion of the gel is increased at a low viscosity. Viscosity affects the dispersed area. Thus, the greater the viscosity value of the gel preparation, the greater is the resistance of the gel preparation to spread, resulting in a decreasing dispersion value. Conversely, if the viscosity value of the gel preparation is getting smaller, the resistance of the gel preparation to spread will also be getting smaller, and so it will have a wide dispersion. The spreadability of the GEGPA formulation in the $\mathrm{F} 3$ group is wider than in the other groups. So, when applied to the application site, this ensures that the formulation maintains a good wet contact time.

Therefore, the active ingredients used in these formulations can be combined with the excipients used in all of these gel formulations. From the comparison of the three formulations above, it can be seen that the third formulation experienced the best release of active ingredients compared with other formulations. In an in vitro study, it was found that formula 3 was released by permease diffusion of $94.01 \%$ for 8 hours, so that formula 3 can describe the increase of the active ingredient penetration and absorption.

The patient's well-being may be harmed by a delayed tooth extraction socket healing process, which increases the risk of infection. The proliferation phase of fibroblast proliferation is a crucial stage in the healing process. Bone development in the socket is facilitated by fibroblasts made up of extracellular matrix and collagen fibers. Fibroblasts are particularly critical cells in the early stages of wound healing, and they begin to form on the third day following injury during the proliferative stage. Fibroblasts begin to move to the wound site and proliferate between days 3 and 5 , resulting in a dominance of their numbers on the wound site. ${ }^{40}$ The use of GEGPA inserted into the tooth sockets of mice shows an increase in the number of fibroblasts on days 3 and 5. Phytochemical compounds in GEGPA such as lectins, palmitic acid, leucocyanidin, quercetin, 3-O-galactoside, 3-O-glucoside, and 3-O-rhamnosyl glucoside can be released from the gel, and play an important role in activating PDGF-BB and TGF- $\beta 1,{ }^{18}$ so that they can increase 
fibroblasts' proliferation in the tooth socket area. The distribution of these compounds in the form of a gel can certainly accelerate wound healing.

\section{Conclusions}

The formulation of M. paradisiaca var. sapientum (L.) kuntze extract with HPMC and propylene glycol obtained a gel preparation, GEGPA, that was organoleptically stable and met the topical gel standard for wounds in the oral cavity.

\section{Funding}

This study was funded by Universitas Airlangga and the Indonesian Ministry of Research, Technology, and Higher Education.

\section{Conflict of Interest}

None declared.

\section{Acknowledgments}

We would like to thank the Chancellor of Universitas Airlangga who has funded this research through the research grant program of the Indonesian Ministry of Research, Technology, and Higher Education.

\section{References}

1 Rodrigues M, Kosaric N, Bonham CA, Gurtner GC. Wound healing: a cellular perspective. Physiol Rev 2019;99(01):665-706

2 Gonzalez AC, Costa TF, Andrade ZA, Medrado AR. Wound healing a literature review. An Bras Dermatol 2016;91(05):614-620

3 Cho YD, Kim KH, Lee YM, Ku Y, Seol YJ. Periodontal wound healing and tissue regeneration: a narrative review. Pharmaceuticals (Basel) 2021;14(05):456. Doi: 10.3390/ph14050456

4 Abbas Shamash MS, Zaidan TF. Curcumin modulate TGFßii-R to improve healing of oral ulceration. Int J Pharm Res 2020; 12:1288-1294

5 Sood A, Granick MS, Tomaselli NL. Wound dressings and comparative effectiveness data. Adv Wound Care (New Rochelle) 2014;3 (08):511-529

6 Leppert W, Malec-Milewska M, Zajaczkowska R, Wordliczek J. Transdermal and topical drug administration in the treatment of pain. Molecules 2018;23(03):681

7 Garg T, Rath G, Goyal AK. Comprehensive review on additives of topical dosage forms for drug delivery. Drug Deliv 2015;22(08): 969-987

8 Ibrahim SA, Elkot RA, Soliman HE. Lactic acid 5\% mouth wash vs Kenalog in Orabase $0.1 \%$ for treatment and prophylaxis of recurrent aphthous ulcer. J Cosmet Dermatol 2020;19(04): 964-969

9 Hammad HM, Hammad MM, Abdelhadi IN, Khalifeh MS. Effects of topically applied agents on intra-oral wound healing in a rat model: a clinical and histomorphometric study. Int J Dent Hyg 2011;9(01):9-16

10 Rajabalaya R, Musa MN, Kifli N, David SR. Oral and transdermal drug delivery systems: role of lipid-based lyotropic liquid crystals. Drug Des Devel Ther 2017;11:393-406

11 Ruela ALM, Perissinato AG, Lino Mde S, Mudrik PS, Pereira GR. Evaluation of skin absorption of drugs from topical and transdermal formulations. Braz J Pharm Sci 2016;52(03):527-544

12 Benson HAE, Grice JE, Mohammed Y, Namjoshi S, Roberts MS. Topical and transdermal drug delivery: from simple potions to smart technologies. Curr Drug Deliv 2019;16(05):444-460
13 Kappelle WFW, Siersema PD, Bogte A, Vleggaar FP. Challenges in oral drug delivery in patients with esophageal dysphagia. Expert Opin Drug Deliv 2016;13(05):645-658

14 Kumar KPS, Bhowmik D, Duraivel S, Umadevi M. Traditional and medicinal uses of banana. J Pharmacogn Phytochem 2012;1(03): 51-63

15 Imam MZ, Akter S. Musa paradisiaca l. and musa sapientum l.: a phytochemical and pharmacological review. J Appl Pharm Sci 2011;1(05):14-20

16 Budi HS, Juliastuti WS, Christy BR. Antimicrobial activity of musa paradisiaca var. sapientum on enterococcus faecalis viability. Malays J Med Health Sci 2020;16(04):17-21

17 Abdel Ghany TM, Ganash M, Alawlaqi MM, Al-Rajhi AMH. Antioxidant, antitumor, antimicrobial activities evaluation of musa paradisiaca 1. Pseudostem exudate cultivated in Saudi Arabia. Bionanoscience 2019;9(01):172-178

18 Budi HS, Soesilowati P, Imanina Z. Gambaran histopatologi penyembuhkan luka pencabutan gigi pada makrofag dan neovaskular dengan pemberian getah batang pisang ambon. Maj Kedokt Gigi Indones 2017;3(03):3-9

19 Budi HS, Juliastuti WS, Ariani W. Mtt-based cytotoxic evaluation of ambonese banana stem sap (Musa paradisiaca var. Sapientum (L.) Kuntze) on FIBROBLAST CELLS. Periód Tchê Quím 2020;17 (36):624-633

20 Budi HS, Astuti ER. The MMP-2, MMP-9 expression and collagen density of the ambonese banana stem sap administration on wound healing. J Int Dent Med Res 2019;12(02): 492-497

21 Allen L v, Ansel HC. Ansel's Pharmaceutical Dosage Forms and Drug Delivery Systems. Ansel's Pharmaceutical Dosage Forms and Drug Delivery Systems 10th edition. Philadelphia: Lippincott Williams \& Wilkins; 2014

22 Noval N, Rosyifa R, Annisa A. Effect of HPMC concentration variation as gelling agent on physical stability of formulation gel ethanol extract bundung plants (Actinuscirpus grossus). Proceedings of the First National Seminar Universitas Sari Mulia, NS-UNISM 2019, 23rd November 2019, Banjarmasin, South Kalimantan, Indonesia. Doi: 10.4108/eai.23-11-2019.2298326

23 Gikonyo D, Gikonyo A, Luvayo D, Ponoth P. Drug expiry debate: the myth and the reality. Afr Health Sci 2019;19(03):2737-2739

24 Patil A, Bhide S, Bookwala M, et al. Stability of organoleptic agents in pharmaceuticals and cosmetics. AAPS PharmSciTech 2018;19 (01):36-47

25 Ueda CT, Shah VP, Derdzinski K, et al. Topical and transdermal drug products. Pharmacop Forum 2010;17(04):750-764

26 Khoswanto $C$. A new technique for research on wound healing through extraction of mandibular lower incisors in Wistar rats. Eur J Dent 2019;13(02):235-237

27 Raj GM, Raveendran R. Introduction to Basics of Pharmacology and Toxicology: Volume 1: General and Molecular Pharmacology: Principles of Drug Action. 1st edition. Singapore: Springer; 2019

28 Chillistone S, Hardman JG. Modes of drug elimination and bioactive metabolites. Anaesth Intensive Care Med 2020;21(09):388-391

29 Caldwell J, Gardner I, Swales N. An introduction to drug disposition: the basic principles of absorption, distribution, metabolism, and excretion. Toxicol Pathol 1995;23(02):102-114

30 Drumond N, Stegemann S. Better medicines for older patients: considerations between patient characteristics and solid oral dosage form designs to improve swallowing experience. Pharmaceutics 2020;13(01):32. Doi: 10.3390/pharmaceutics13010032

31 Hishikawa Y, Kakino Y, Tsukamoto H, Tahara K, Onodera R, Takeuchi H. Control of drug diffusion behavior of xanthan and locust bean gum gel by agar gel. Chem Pharm Bull (Tokyo) 2016; 64(10): 1450-1457

32 Popov TA, Emberlin J, Josling P, Seifalian A. In vitro and in vivo evaluation of the efficacy and safety of powder hydroxypropylmethylcellulose as nasal mucosal barrier. Med Devices (Auckl) 2020;13:107-113 
33 Rowe RC, Paul JS, Owen SC. Handbook of Pharmaceutical Excipients. London: Pharmaceutical Press; 2006

34 Allen LV. BLT in propylene glycol topical gel. US Pharm 2013;38 (12):36-37

35 Nayak AK, Panigrahi PP. Solubility enhancement of etoricoxib by cosolvency approach. ISRN Phys Chem 2012;2012:820653. Doi: $10.5402 / 2012 / 820653$

36 Jagtap S, Magdum C, Jadge D, Jagtap R. Solubility enhancement technique: a review. J Pharm Sci Res 2018;10(09):2205-2211

37 Baliga S, Muglikar S, Kale R. Salivary pH: a diagnostic biomarker. J Indian Soc Periodontol 2013;17(04):461-465
38 Garg A, Aggarwal D, Garg S, Singla AK. Spreading of semisolid formulations: an update. Pharm Technol 2002;26(09): 84-105

39 Nurman S, Yulia R, Irmayanti, Noor E, Sunarti TC. The optimization of gel preparations using the active compounds of arabica coffee ground nanoparticles. Sci Pharm 2019;87(04):32

40 Amaliya A, Muhaimina RK, Susanto A, Sutjiatmo AB. Histological assessment of palatal donor site wound healing after application of Moringa oleifera Lamarck leaf extract in rats. Eur J Dent 2019; 13(02):248-254 